\title{
Comparison of Alteration in Growth, Physiological and Biochemical Attributes of Ten Maize (Zea mays L.) Varieties under Arsenic Stress: Susceptibility and Tolerance
}

\author{
Muhammad Atif, Shagufta Perveen* \\ Department of Botany, Government College University Faisalabad, Pakistan
}

Received: 16 January 2021

Accepted: 10 April 2021

\begin{abstract}
The current findings concluded the reverse impacts of arsenic (As) stress on ten contrasting maize varieties (Malika 2016, Sahiwal 2002, Agaitti 2002, Pearl, Akbar, Pak Afghoi, Neelum, Pioneer, Sadaf, MMRI-Yellow). A pot experiment was designed to screen out the tolerant and susceptible maize varieties at Government College University Faisalabad. Genetic variability among the maize varieties explodes their individual coping traits either tolerant or sensitive against As accumulation. The exposure to different levels of As $(50,100 \mathrm{mg} / \mathrm{kg})$ stress were examined. Application of As stress substantially decreased the growth attributes in all maize varieties. Arsenic also induced a significant decline in chlorophyll contents in all maize varieties, especially in sensitive varieties. Remarkable decrease was observed in growth and chlorophyll attributes, while increase was recorded in malondialdehyde (MDA), hydrogen peroxide $\left(\mathrm{H}_{2} \mathrm{O}_{2}\right)$, ascorbic acid (ASA), superoxide dismutase (SOD), peroxidase (POD) and catalase (CAT) activities. Results of current study show that variety Pearl of maize was more tolerant with minimum decrease in growth, while Akbar variety was more sensitive with maximum decrease in all growth attributes against As stress. Furthermore, maize varieties namely Neelum, Sahiwal, Poineer and Pak Afghoi also presented as tolerant varieties, while Sadaf, MMRI and Malika proved as moderately sensitive against As stress. The higher As tolerance of Pearl variety was associated with persistency to maintain higher growth and chlorophyll contents under As stress as compared to the other varieties.
\end{abstract}

Keywords: oxidative stress, arsenic stress, maize varieties, chlorophyll contents

*e-mail: perveens1@yahoo.com 


\section{Introduction}

Maize (Zea mays L.) is one of the most important cultivated cereal crops all over the world [1]. Maize production increase every year in Pakistan, but it is very low as compared to other corn producing countries. Being important as well as prime industrial crops, it is not only consumed and commercially marketed as feed and fodder crop but also utilized as raw material in ethanol production. A massive consumption of heavy metals and metalloids results in polluted soil and improper release of waste water from tanneries and industries which caused water and soil pollution by putting food conservation into risk [2, 3]. Arsenic has retained its place as the $1^{\text {st }}$ toxic hazardous pollutant [4], due to its enormous toxic perspectives. Arsenic (As) is major heavy metalloid, which is scarcely harmful for human and plant health [5]. As stress leads to limit the oxidation of biological membranes, which resulted in limitation of growth, reduced shoot and root growth leading to minimal increase in yield [6]. As is an important environmental pollutant and recently, its inclusion in soil is evaluated between $52,000-112,000$ tons year-1 because of additionally utilized anthropogenic activities [7]. These toxic elements are easily transported to aerated parts of plants from soil and cause significant modifications and malfunctions in morphological, physiological, and biochemical attributes of plants only at low concentration [8]. Concentration of As for drinking in well water in Pakistan is found about $12-488 \mu \mathrm{g} / \mathrm{L}$ [9]. At higher concentration As is lethal for plant growth [10]. A major focus of researchers has attained major attention on arsenic related hazardous threats [11, 12, 13]. Improper and frequent industrial and irregular agricultural utilization impacts have elevated its concentration into environment [14, 15]. Heavy metals interrupted with metabolic system which leads to constraint the plant growth and reduced yield [16]. Arsenic along with $\mathrm{Zn}$ enhances its uptake both in leaves and fronds [17]. The As interruption may alter many metabolic pathways and processes and limited plant growth and maturity in a lot of plant species [18]. Accumulated As contents causes a reduction in branched roots elongation and, also resulted in chlorosis and the shrinkage leading to necrosis of the aerial parts of plants [19]. Reduction in root and shoot biomass about 25 and $20.62 \%$ was found in wheat under As stress [20]. Moreover, massive findings also demonstrated same results in growth as well as yield reduction under As stress in Pteris vittata [21], in tomato [22] and in wheat [23]. Such toxic elements lead to disarrangement in photosynthetic systems by degrading chlorophyll contents in the leaves to restrict photosynthesis [24]. Reverse effects has also been illustrated to growth retardation, chlorophyll diminishing, and curtailing the photosynthetic activity [25]. Stomata closure due to As causes deprivation of $\mathrm{CO}_{2}$; thus it takes over $\mathrm{C}$-assimilation in photosynthetic process and also lower the transpiration rate [26]. Similar trend was perceived in wheat when a tremendous reversed impact was observed in wheat in chlorophyll $a$, and chlorophyll $b$ contents as the As concentration increased [27]. They also corroborated that As limited the chlorophyll contents as it assembles in the leaves and massive accumulation in specified fragments, and strap with -SH base of protein and burst up the constructive shape and functionality of chloroplast. Up to date, very few pieces of investigations are accessible about such ecotoxic hazardous effects of heavy metalloid. Arsenic toxicity on growth, oxidative stress, non oxidative enzymatic stress and chlorophyll contents of all these maize varieties in our experiment were examined to choose the more tolerable varieties that can grow better under As stressed conditions. Therefore, the current study was carried out to investigate the influence of As on ten different maize varieties to calculate the negative impacts of arsenic and quantification of sensitive and tolerant varieties after measuring maize growth, chlorophyll contents, enzymatic and non-enzymatic antioxidants.

\section{Experimental}

Seeds of ten different maize varieties (Malika 2016, Sahiwal 2002, Agaitti 2002, Pearl, Akbar, Pak Afghoi, Neelum, pioneer, Sadaf, MMRI-Yellow) were collected from the Ayub Agricultural Research Institute (AARI) Faisalabad and Maize \& Millets Research Institute (MMRI)Yusafwala Sahiwal. The seeds were sown in sand filled plastic pots arranged in a completely randomized design (CRD). After germination, the seven days old plants were subjected to arsenic (As) stress with three levels $(0,50,100 \mathrm{mg} / \mathrm{kg})$ along with full strength Hoagland's nutrient solution. After the arsenic treatments, the data of four week old plants for the various attributes were recorded.

Two plants per pot were taken for measuring growth attributes, fresh weights and lengths (shoots and roots) of the maize plants individually. Then these plants were air dried and placed in oven bearing temperature $65^{\circ} \mathrm{C}$ for 3 days for dry weights (shoots and roots).

Fresh leaf $(0.5 \mathrm{~g})$ was grinded in $10 \mathrm{~mL}$ of acetone $(80 \%, \mathrm{v} / \mathrm{v})$. The aliquot was read at 663 and $645 \mathrm{~nm}$ for determining the chlorophyll $a$ and $b$ contents as described by Arnon [28].

Ascorbic acid was measured by using method of Mukherjee and Choudhuri [29]. Plant material (0.25 g) was grinded in $10 \mathrm{~mL}$ of trichloro acetic acid (TCA (6\%); MP Biomedicals, de Kaysersberg Illkirch, France). After mixing $4 \mathrm{~mL}$ material with $2 \mathrm{~mL}$ dinitrophenyl hydrazine, $10 \%$ thiourea was added (one drop) for each. Then transfer the reaction mixture into a water bath at $100^{\circ} \mathrm{C}$ for $15 \mathrm{~min}$. and then cooled at room temperature for adding $5 \mathrm{~mL}$ of $\mathrm{H}_{2} \mathrm{SO}_{4}(80 \%$, $\mathrm{v} / \mathrm{v}$; Merck, Germany). After shaking the mixture, its absorbance was noted at $530 \mathrm{~nm}$. 
Fresh sample of leaf material $(0.25 \mathrm{~g})$ was grinded in $3 \mathrm{~mL}(5 \% ; \mathrm{w} / \mathrm{v})$ of TCA and after centrifugation at $12,000 \times g$ for $15 \mathrm{~min}, 4 \mathrm{ml}$ of thiobarbituric $(0.5 \%$, w/v; mol. wt. 144.5; Sigma- Aldrich Chemie GmbH, Steinheim, Germany) acid in $1 \mathrm{~mL}$ of supernatant. After incubation at $95^{\circ} \mathrm{C}$ and then cooled in chilled water, the absorption was read at 532 and $600 \mathrm{~nm} \mathrm{[30].}$

Hydrogen peroxide was calculated by using the method of Velikova [31]. Fresh leaf tissue $0.5 \mathrm{~g}$ was grounded with trichloro acetic acid (TCA $5 \mathrm{ml}$ of $0.1 \%$ $\mathrm{w} / \mathrm{v}$ ) and centrifuged for 15 minutes at $12,000 \times \mathrm{g}$ after that addition of $0.5 \mathrm{~mL}$ phosphate buffer with $\mathrm{pH} 7.0$ and $1 \mathrm{ml}$ potassium iodide was made. Absorbance will be taken at $390 \mathrm{~nm}$.

Into a prechilled pestle and mortar, fresh leaf material $(0.5 \mathrm{~g})$ was ground in $5 \mathrm{~mL}$ of $50 \mathrm{mM}$ sodium phosphate buffer ( $\mathrm{pH}$ 7.8). The homogenate was centrifuged at $15,000 \times g$ for $15 \mathrm{~min}$ at $4^{\circ} \mathrm{C}$. The supernatant was separated and used for the determination of activities of the enzymes.

Superoxide dismutase activity was measured as described in the method of Giannopolitis and Ries [32] and absorbance was measured at $560 \mathrm{~nm}$. Following the protocol of Chance and Maehly [33], the enzyme extract was treated step-wise and the activity of catalase enzyme was measured at $240 \mathrm{~nm}$. Adopting the protocol of Chance and Maehly [33] the reaction mixture was prepared and absorbance was recorded at $470 \mathrm{~nm}$. All the data were analyzed by analysis of variance (ANOVA) and significant differences of arsenic stress were determined with the least significant differences (LSD) test at $\mathrm{P}<0.05$ level.

\section{Results and Discussion}

Analysis cleared that not only shoot and root fresh biomasses but also dry biomass of all varieties of maize (Malika 2016, Sahiwal 2002, Agaitti 2002, Pearl, Akbar, Pak Afghoi, Neelum, Pioneer, Sadaf, MMRI yellow) were reduced under varying (50 and $100 \mathrm{mg} / \mathrm{kg}$ ) arsenic (As) stress conditions (Figs 1,2 a-b). However dissimilarity of decrease in reduction was recorded in genetically different varieties. Akbar variety showed remarkable decrease in shoot fresh and dry weight, while pearl variety showed minimum reduction in shoot fresh and dry weight when compared with other maize varieties. Maximum decrease was observed in Akbar variety, while minimal decrease was observed in Pearl, Agaiti 2002, Poineer and Malika 2016 maize varieties. Root and shoot lengths significantly decreased $(\mathrm{P} \leq 0.001)$ with increase in As stress levels. Noticeable decrease was observed in all maize varieties and maximal decrease was observed in Akbar, Pak Afghoi and Sadaf maize varieties in all growth attributes. However, the significant decrease was observed in all growth attributes in Akbar, Sadaf, Malika, MMRI-Yellow maize varieties, while the varieties Pearl, MMRI-Yellow, Neelum and Poineer exhibited tolerance against As stress. Retardation in growth might be related to reduced photosynthesis due to the apparatus that involved in light absorption and oxidative stress disturbance to the metabolic process [34]. In current findings, it was determined that As stress induced more negative effects on variety Akbar and was more deleterious to all sensitive maize varieties as compared to variety Pearl. Several researchers find out the individual outcomes of negative impacts of As stress on maize and other plants [35, 36]. As-uptake from root to shoot transported through xylem tissue and distributed in different plant parts into cells of plant [37]. Arsenite is detoxified when it form complex with thiol rich peptide and these complexes stored in the vacuoles of root cells and its efflux carried out at the very low concentration [38]. Uptake of arsenic, negatively affected the metabolism and growth of plant which resulted in overall productivity reduction [39]. It was reported that higher As levels caused stunted growth in different plants such as Oryza sativa and Cicer arietinum L. [40]. Arsenic stress caused retarded growth of root and shoot by reducing the number of leaves, area of leaf and fresh and dry mass of plants [41]. Arsenic concentration in soil and water disturbed normal metabolic and biochemical pathways by disturbing the nutrients uptake, absorption of nutrients, functioning of photosynthetic system and essential ions replacement with adenosine triphosphate [42]. At present, As stress was correlated with minimal leaf photosynthetic operation and malfunctioning of light capturing structure in the leaves. Furthermore, proteins are denaturized by the heavy metalloids (As) after splitting up the hydrogen-sulfur linkage, which leads to stunted growth and enlargement in plants [43]. Similar findings have been reported by As induced plants as reported [44] that As stress tremendously retarded the maize growth as compared to non-stressed plants. Current conclusions are matched with previous investigations in maize [45] and demonstrated in many other plant species such as turnip [46] and rice [47]. Accumulation of As in plants resulted in various toxic reactions and affected the growth, morphological and physiological processes of the plant [48]. This caused reduction in the rate of photosynthesis, which led to reduction in root and shoot growth and grain yield [49]. Chlorophyll $a$ and $b$ contents declined significantly under As stressed conditions in all maize varieties. Arsenic stress had pronounced consequences on chlorophyll $a$ and especially in chlorophyll $b$ (Fig. 2 g-h). However, remarkable decline in Chlorophyll $b$ was observed in Akbar, Agaiti 2002, Sadaf and MMRI-Yellow maize varieties. This decline was also observed by [50] in hydrophytes and wheat under cadmium stress. However, more decrease in chlorophyll $a$ was observed by [26] under As stress. Current results indicated more decrease in Chlorophyll $b$ indicate sensitivity of certain varieties under As stress. High sensitivity was proved under heavy metal stress was observed 


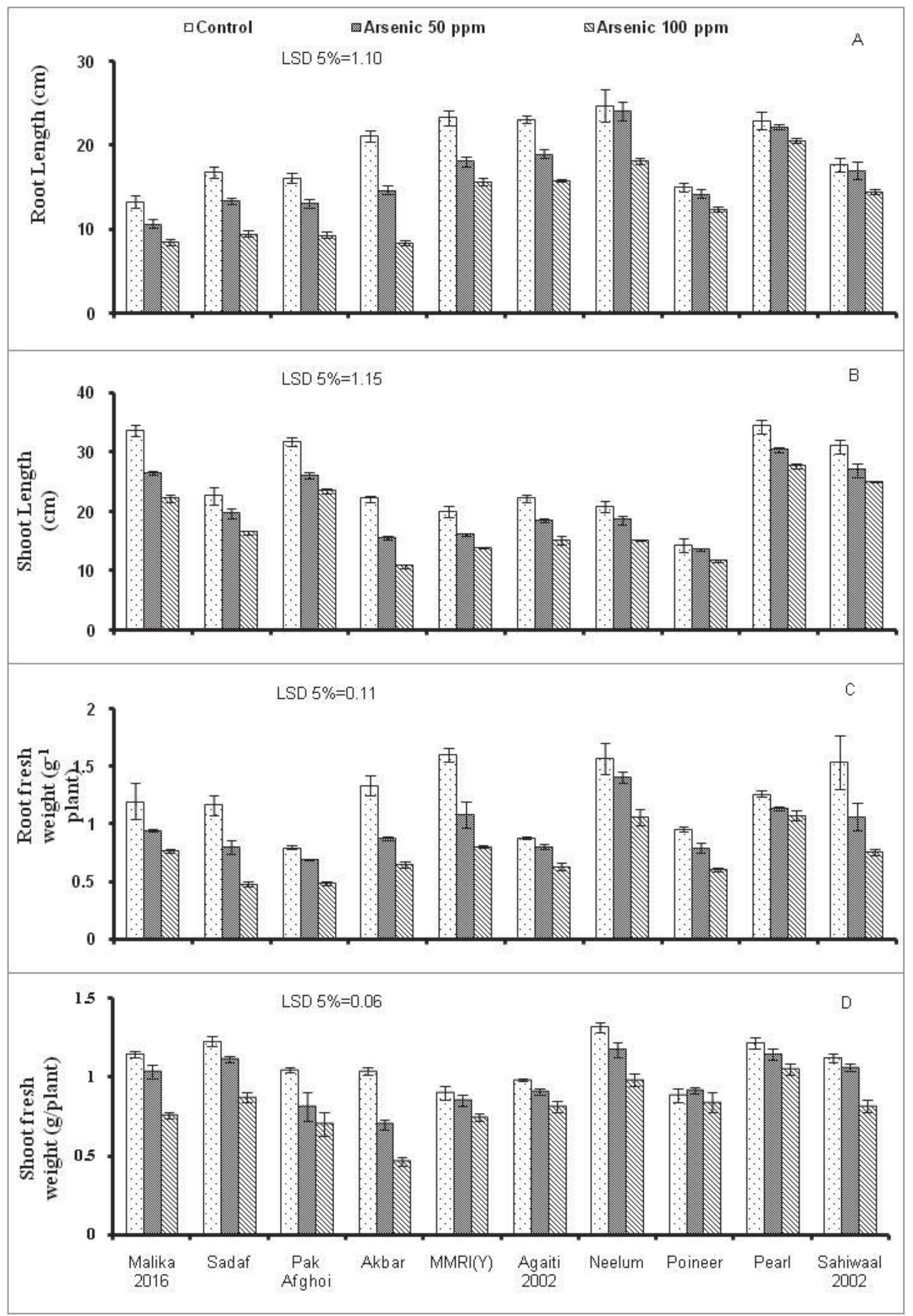

Fig. 1. Root length, shoot length, root fresh weight, shoot fresh weight of arsenic-stressed and non-stressed plants of ten varieties of maize (Zea mays L.). 

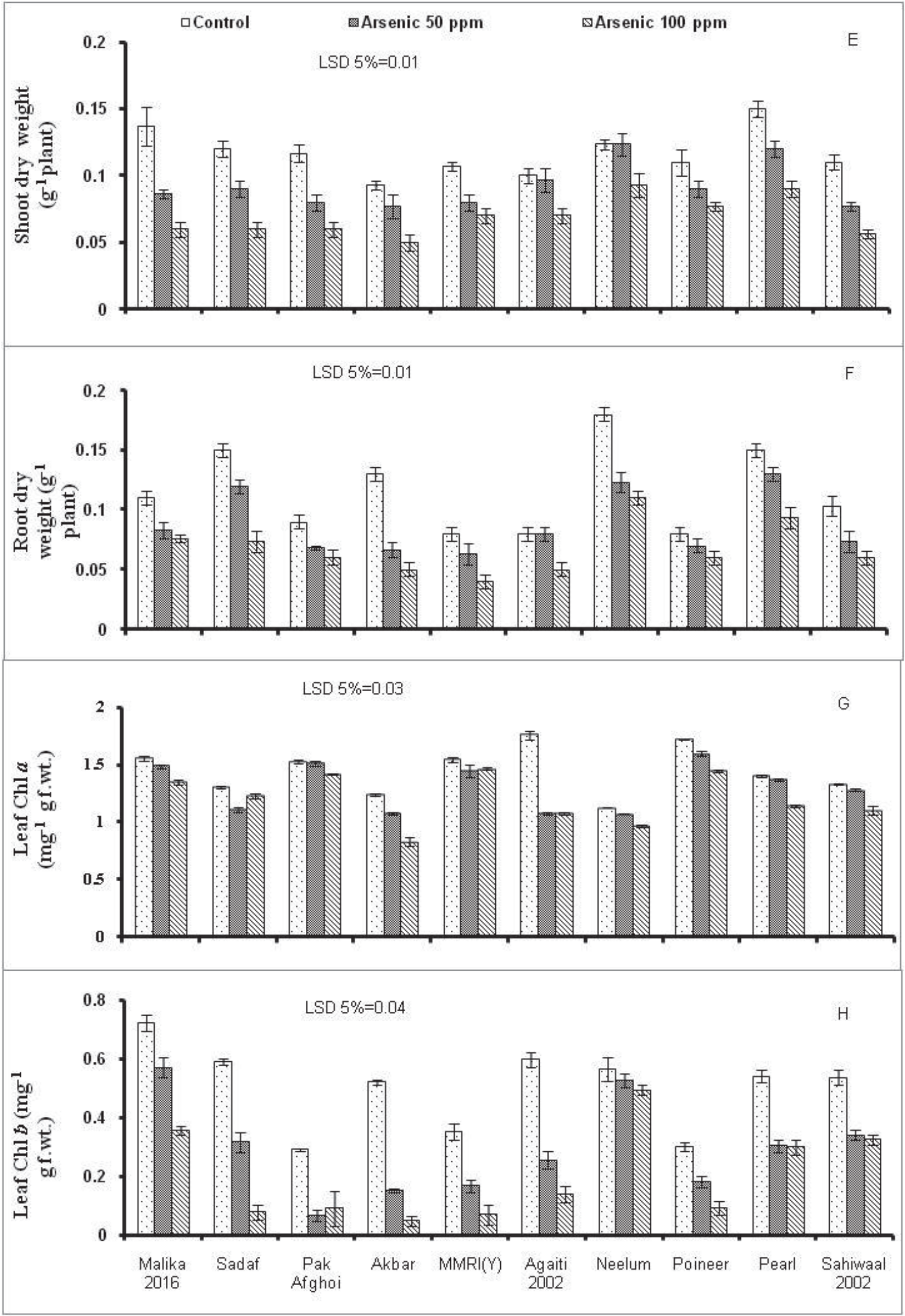

Fig. 2. Shoot dry weight, root dry weight, chlorophyll $a$ and $b$ contents of arsenic-stressed and non-stressed plants of ten varieties of maize (Zea mays L.). 
Table 1. Mean squares from analysis of variance of the data for various growth attributes, photosynthetic pigments, $\mathrm{MDA}, \mathrm{H}_{2} \mathrm{O}_{2}$, ascorbic acid contents and activities of catalase, peroxidase, superoxide dismutase enzymes of maize (Zea mays L.) varieties under arsenic stress and non-stress conditions.

\begin{tabular}{|c|c|c|c|c|}
\hline Source of variation & Var (var) & Stress (S) & $\operatorname{Var} \times \mathrm{S}$ & Error \\
\hline Shoot fresh wt & $0.174 * * *$ & $0.611 * * *$ & $0.019 * * *$ & 0.004 \\
\hline Root fresh wt & $0.431 * * *$ & $1.869^{* * *}$ & $0.042 * *$ & 0.016 \\
\hline Shoot dry weight & $0.001 * * *$ & $0.017 * * *$ & $2.646^{*}$ & 1.277 \\
\hline Root dry weight & $0.006 * * *$ & $0.017 * * *$ & $5.085^{* * *}$ & 1.235 \\
\hline Shoot length & $335.061^{* * *}$ & $383.555^{* * *}$ & $5.866^{* * *}$ & 1.511 \\
\hline Root length & $143.508^{* * *}$ & $282.084 * * *$ & $8.251 * * *$ & 1.377 \\
\hline Chl $a$ & $0.345^{* * *}$ & $0.184 * * *$ & $0.086^{* * *}$ & 0.001 \\
\hline $\mathrm{Chl} b$ & $0.172 * * *$ & $0.719 * * *$ & $0.018 * * *$ & 0.001 \\
\hline MDA & $123.376^{* * *}$ & $1528.945 * * *$ & $86.335^{* * *}$ & 0.679 \\
\hline $\mathrm{H}_{2} \mathrm{O}_{2}$ & $55.444 * * *$ & $144.16^{* * *}$ & $5.692 * * *$ & 0.419 \\
\hline Ascorbic acid & $617.501 * * *$ & $3132.238^{* * *}$ & $96.927 * * *$ & 0.652 \\
\hline Catalase & $67.800^{* * *}$ & $54.726^{* * *}$ & $7.705^{* * *}$ & 0.063 \\
\hline Peroxidase & $236.361 * * *$ & $641.096^{* * *}$ & $16.465^{* * *}$ & 0.954 \\
\hline SOD & $741.820 * * *$ & $1395.7324 * * *$ & $20.677 * * *$ & 6.211 \\
\hline Df & 9 & 2 & 18 & 60 \\
\hline
\end{tabular}

$*, * *$, and $* * *=$ significant at $0.05,0.01$, and 0.001 levels, respectively; $\mathrm{df}=$ degrees of freedom; ns = non-significant; $\mathrm{wt}=$ weight; $\mathrm{chl}=$ chlorophyll; $\mathrm{MDA}=$ malondialdehyde; $\mathrm{SOD}=$ superoxide dismutase; $\mathrm{H}_{2} \mathrm{O}_{2}=$ hydrogen peroxide

in photosynthetic pigments and thus proved as definitive indicators to ascertain the contradicting impacts of heavy metal stress specifically in Chl $b$. Photosynthetic systems are prominently damaged when exposed to high concentrations of As stress and disturbing the whole photosynthetic process [51]. The several abiotic stresses have massive impact on photosynthetic process which linked with abundant reactive oxygen species (ROS) production [52]. Similarly, heavy metal stress also negatively affected the chlorophyll contents and gas exchange attributes [53]. Increasing soil As levels curtailed the growth and development of rice plants by causing oxidative stress and reduction in photosynthetic activity [54]. It is already documented that relatively high levels of As hindered the growth of roots and minimize the biomass of rice (Oryza sativa L.) [55].

This massive diminishing trend in the production of chlorophyll was accredited to abrupt lamellar bodies in chlorophyll comprising proteins. While investigating on soybean, the reduced chlorophyll contents impaired with destructive thylakoid membranes under As stress [56]. It could also interfere with the amalgamation of chlorophyll molecules into photosystems to form pigment-protein complexes [57]. Response exhibited by Pearl ascribed to development of more chlorophyll pigments and enhanced as observed in present study. Data analysis of ascorbic acid contents showed a remarkable increase under As stress in all maize varieties (Fig. 3K). It has already determined that ascorbate-glutothione (ASA-GSH cycle) being as the main pathway which is the scavenging mechanism for the ROS successfully in plants for competing under abiotic and biotic stress [58]. Maximum increase was observed in Akbar, Agaiti 2002, while minimal increase was observed in Neelum maize variety under arsenic stress. Malondialdehyde (MDA) contents remarkably increased under As stress in all maize varieties (Fig. 3i). The reason behind is lipid peroxidation due to heavy metal toxicity leading to increased MDA contents, which is a biomarker of lipid peroxidation in the plants [59, 60]. It can damage the membrane properties, which is estimated from the increased MDA contents. Similar findings have been concluded in Arabdopsis thaliana exposed to As stress [61]. Malondialdehyde (MDA) is an indicator of occurrence of lipid peroxidation due to oxidative damage, which is detected in spinach leaves when grown in presence of As [62]. As stress leads to remarkable reduction in plant growth and photosynthesis but enhanced in $\mathrm{H}_{2} \mathrm{O}_{2}$, main antioxidant enzymes, MDA, root and shoot As contents [63]. Biotic and abiotic stress in plants cause oxidative damage by the production of reactive oxygen species (ROS), which resulted in degradation of biomolecules, membrane and structural damages [64]. As stressed conditions depicted enhancements in all the activities in $\mathrm{H}_{2} \mathrm{O}_{2}, \mathrm{CAT}$, POD, and SOD contents in all maize varieties (Fig. 3J, Fig. 4L-M). Superoxide dismutase 


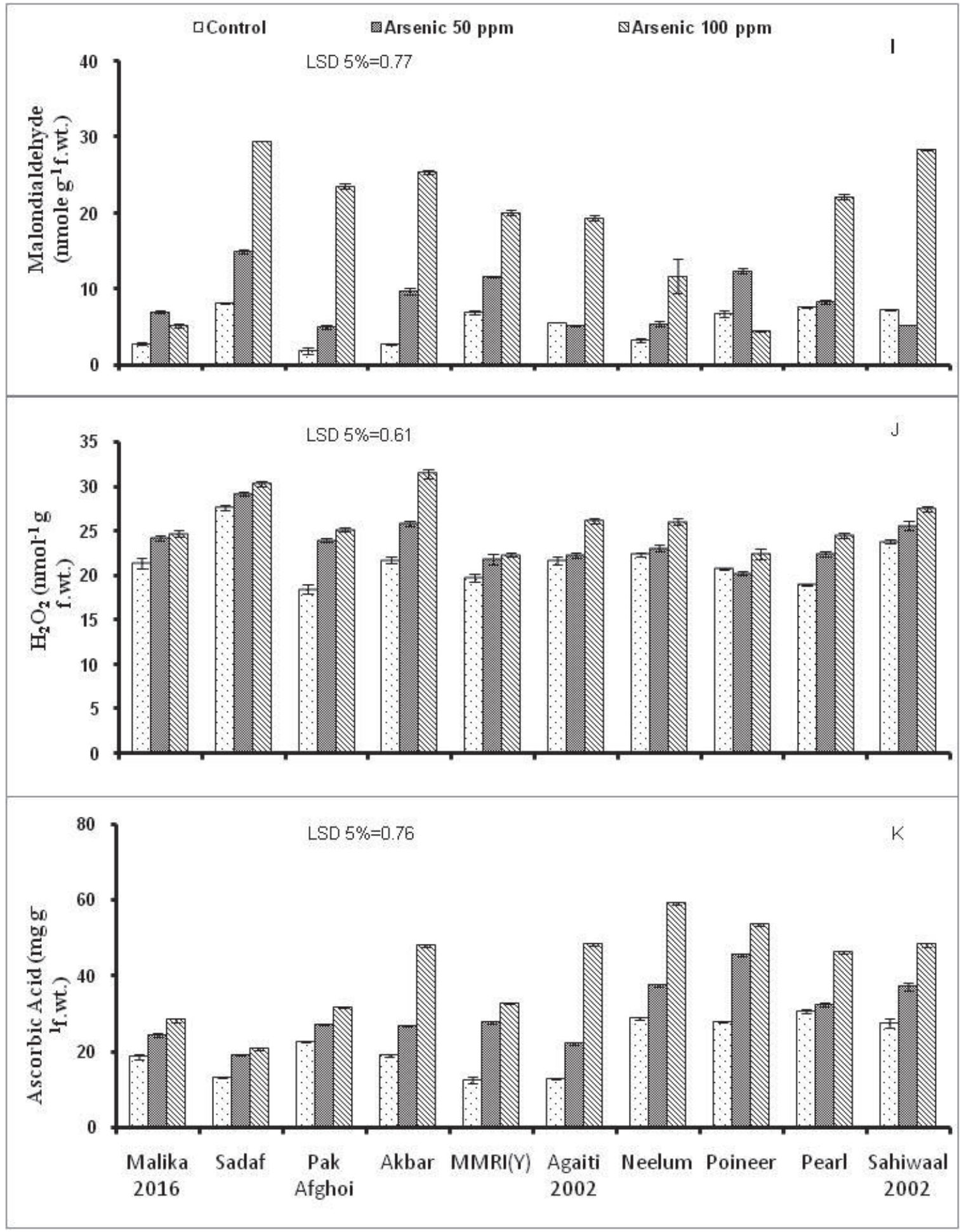

Fig. 3. Ascorbic acid, hydrogen peroxide and malondialdehyde contents of arsenic-stressed and non-stressed plants of ten varieties of maize (Zea mays L.).

(SOD) can eliminate $\mathrm{O}^{2-}$, decrease peroxidation of membrane lipids and cell membrane integrity is intact to the levels of stability, and POD decomposes $\mathrm{H}_{2} \mathrm{O}_{2}$ [65]. Most of the As remains in plant roots that is beneficial for the heavy metalloid detoxification while oxidative stress and anti oxidative parameters induced oxidative damage because of contamination of As in cell wall [66]. Plants have an efficient defense system to combat with the harmful effects of ROS [67]. Present and other studies verified that the activities of POD remarkably increased and having interactive role with heavy metal stress which is proved as that plants coping 

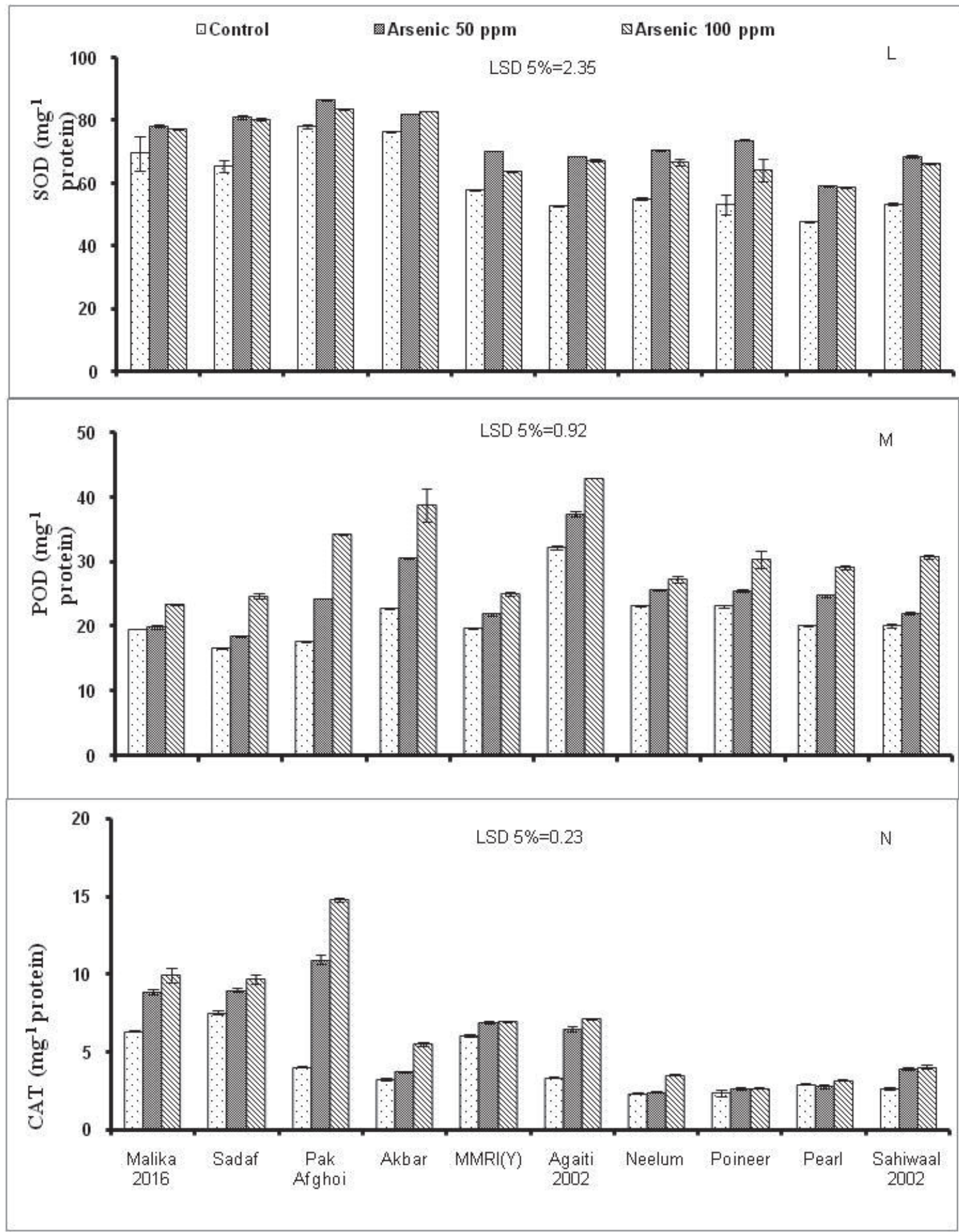

Fig. 4. Superoxide dismutase, peroxidase, catalase enzymes activities of arsenic-stressed and non-stressed plants of ten varieties of maize (Zea mays L.).

capability with negative impacts introduced through heavy metals for the retention of membrane stability [68]. The augmented activity of antioxidant enzymes scavenges excessive ROS production. SOD detoxifies $\mathrm{O}^{2-}$ to $\mathrm{H}_{2} \mathrm{O}_{2}$ and CAT converts $\mathrm{H}_{2} \mathrm{O}_{2}$ to both $\mathrm{O}_{2}$ and $\mathrm{H}_{2} \mathrm{O}_{2}$, while POD plays a vital role in the catalysis of
$\mathrm{H}_{2} \mathrm{O}_{2}$ [69]. Arsenic accumulation imparts a significant change in the activities of CAT and of POD, whereas on the other hand, the comparative less increase was observed in activity of SOD. The marked enhancement in the activity of CAT and POD was more obvious than the SOD. On the contrary, the minute increase in SOD 
activity was due to the enhancement in rate of ROS scavenging by the some other antioxidant enzymes, and increased $\mathrm{H}_{2} \mathrm{O}_{2}$ due to the inactivation of SOD may function in oxidative stress leading to the induction of peroxidase antioxidant systems [70].

\section{Conclusions}

Limitations in growth attributes of all ten maize varieties under arsenic stress was due to its toxic nature that caused degrading chlorophyll contents, oxidative stress and scavenging of ROS. Of all maize varieties Pearl, Neelum, Sahiwal, Pioneer and Pak Afgoi showed better growth under arsenic stress, while Akbar and Sadaf proved sensitive against arsenic stress. The As-tolerant maize varieties exhibited relatively less reduction in all growth attributes. Increasing CAT activity has protective effect on growth and photosynthesis capability of maize to cope with As originated oxidative stress. Overall, As stress created marked differences in the activities of CAT, POD, SOD and all growth parameters in tolerant maize varieties as compared to susceptible maize varieties concluding that maize varieties having different lineage and pedigrees differed in some specified and strategic mechanisms of As stress tolerance.

\section{Acknowledgements}

The data presented in this manuscript is the part of $\mathrm{Ph} . \mathrm{D}$. research of the first author and the technical and moral support provided by $2^{\text {nd }}$ author Department of Botany Government College University Faisalabad is highly appreciated.

\section{Conflict of Interest}

The authors declare no conflict of interest.

\section{References}

1. ASHRAF U., SALIM M.N., SHER A., SABIR S.R., KHAN A., PAN S., TANG X., Maize growth, yield formation and water nitrogen usage in response to varied irrigation and nitrogen, supply under semi-arid climate. Tur. J. of Field Crops, 21 (1), 88, 2016.

2. SHAHZAD B., TANVEER M., HASSAN W., SHAH A.N., ANJUM S.A.,CHEEMA S.A., ALI I. Lithium toxicity in plants: reasons, mechanisms and remediation possibilities - a review, A review. Plant Physiol. and Biochem., 107, 104, 2016.

3. WHITE P.J., BROWN P.H. Plant nutrition for sustainable development and global health. Annals of Bot., 105, 1073, 2010.

4. ATSDR. (2015) Agency for Toxic Substances and Disease Registry.Priority list of hazardous substances, US Dep. Of Health and Human Services. Website. https://www.atsdr. cdc.gov/spl/resources/2015 atsdr_substance priority list. html. 2015.

5. ANDOSCH A., AFFENZELLER M.J., LUTZ C., LUTZMEINDL U. A freshwater green alga under cadmium stress: ameliorating calcium effects on ultrastructure and photosynthesis in the unicellular model Micrasterias. J. of Plant Physiol., 169, 1489, 2012.

6. BONDADA B.R., MA L.Q. Arsenic hyperaccumulation by Chinese brake fern (Pterisvittata L.). In S. Chandra \& M. Srivastava (Eds.), Pteridology in the new millennium. NBRI Bot., 109, 229, 2003.

7. GUPTA D.K., HUANG H.G., NICOLOSO F.T., SCHETINGER M.R., FARIAS J.G., LI T.Q., RAZAFINDRABLE B.H.N., ARYAL N., INOUHE $\mathrm{M}$. Effect of $\mathrm{Hg}$, $\mathrm{As}$ and $\mathrm{Pb}$ on biomass production, photosynthetic rate, nutrients uptake and phytochelatin induction in Pfaff iaglomerata. Ecotox., 9, 1403, 2013.

8. RASOOL A., XIAO T., FAROOQI A., SHAFEEQUE M., LIU Y., KAMRAN M.A., EQANI S.A.M.A.S. Quality of tube well water intended for irrigation and human consumption with special emphasis on arsenic contamination at the area of Punjab, Pakistan. Env. Geochem. and health, 39 (4), 847, 2017.

9. VANDERENT A., BAKER A.J., REEVES R.D., POLLARD A.J., SCHAT H. Hyperaccumulators of metal and metalloid trace elements: facts and fiction. Plant and Soil, 362 (1-2), 319, 2013.

10. LIU D.G., MIN X.B., KE Y., CHAI L.Y., LIANG Y.J., LI Y.C., WANG Z.B. Co-treatment of flotation waste, neutralization sludge, and arsenic-containing gypsum sludge from copper smelting: solidification/stabilization of arsenic and heavy metals with minimal cement clinker. Env. Sci. and Pol. Res., 25 (8), 7600, 2018.

11. CHEN Y., HAN Y.H., CAO Y., ZHU Y.G., RATHINASABATHI B., MA L.Q. Arsenic transport in rice and biological solutions to reduce arsenic risk from rice. Front. in plant sci., 8, 268, 2017.

12. SHI G.L., ZHU S., BAI S.N., XIA Y., LOU L.Q., CAI Q.S. The transportation and accumulation of arsenic, cadmium, and phosphorus in 12 wheat cultivars and their relationships with each other. J. of Hazard. Mat., 299, 94, 2015.

13. ZARE S., HASHEMINEJAD N., SHIRVAN H.E., HEMMATJO R., SAREBANZADEH K., AHMADI S. Comparing Universal Thermal Climate Index (UTCI) with selected thermal indices/environmental parameters during 12 months of the year. Weath. and clim. ext., 19, 49, 2018.

14. SHAHID M., NIAZI N.K., DUMAT C., NAIDU R., KHALID S., RAHMAN M.M., BIBI I. A meta-analysis of the distribution, sources and health risks of arseniccontaminated groundwater in Pakistan. Env. Pol., 242, 307, 2018.

15. ANJUM S.A., ASHRAF U., KHAN I., TANVEER M., ALI M., HUSSAIN I., WANG L. Chromium and aluminum phytotoxicity in maize: morpho-physiological responses and metaluptake. Clean: Soil, Air, Wat., 44, 1, 2016b.

16. ABID R., MANZOOR M., De OLIVAIRA L.M., Da SILVA E., RATHINASABAPATHI B., RENSING C., MA L.Q. Interactive effects of $\mathrm{As}, \mathrm{Cd}$ and $\mathrm{Zn}$ on their uptake and oxidative stress in As-hyperaccumulator Pterisvittata. Env. Pol., 248, 756, 2019.

17. CHOUDHURY B., CHOWDHURY S., BISVAS A.K. Regulation of growth and metabolisminrice(Oryza sativa L.) 
by arsenic and its possible reversal by phosphate. J. of Plant Int., 6 (1), 15, 2011.

18. CARBONELL-BARRACHINA A.A., AARABI M.A., DELAUNE R.D., GAMBRELL R.P., PATRICK W.H. The influence of arsenic chemical form and concentration on Spartina patens and Spartina alterniflora growth and tissue arsenic concentration. Plant and Soil, 198 (1), 33, 1998.

19. LI C.X., FENG S.L., YUN S., JIANG, L. N., LU, X. Y., $\&$ HOU, X. L. Effects of arsenic on seed germination and physiological activities of wheat seedlings. Journal of Env. Sci., 19 (6), 725, 2007.

20. LI W.X., CHEN T.B., HUANG Z.C., LEI M., LIAO X.Y. Effect of arsenic on chloroplast ultrastructure and calcium distribution in arsenic hyperaccumulator Pteris vittata L. Chemosphere, 62 (5), 803, 2006.

21. CARBONELL-BARRACHINA A., BURLOCARBONELL F., MATAIXBENEYTO J. Arsenic uptake, distribution and accumulation in tomato plants: effect of arsenite on plant growth and yield. Chemosphere, 62, 803, 1995.

22. LIU X., ZHANG S., SHAN X., ZHU Y.G. Toxicity of arsenate and arsenite on germination, seedling growth and amylolytic activity of wheat. Chemosphere, 61 (2), 293, 2005.

23. BANKJI I., SLEIMI N., LOPEZ-CLIMENT M.F., PEREZ-CLEMENTE R.M., GOMEZ-CADENAS A. Effect of combined abiotic stresses on growth, trace element accumulation and phytohormone regulation in two halophytic species. J. of Plant Growth Reg., 33 (3), 632, 2014.

24. QADIR S., QURESHI M.I., JAVED S., ABDIN M.Z. Genotypic variation in phytoremediation potential of Brassica juncea cultivars exposed to $\mathrm{Cd}$ stress. Plant Sci., 167 (5), 1171, 2004.

25. GUPTA D.K., INOUHE M., RODRIGUEZ-SERRANO M., ROMERO-PUERTAS M.C., SANDALIO L.M. Oxidative stress and arsenic toxicity: role of NADPH oxidases. Chemosphere, 90 (6), 1987, 2013.

26. ANJUM S.A., TANVEER M., HUSSAIN S. Osmoregulation and antioxidant production in maize under combined cadmium and arsenic stress. Environmental Sci. and Pol. Res., 23, 11864, 2016c

27. LI C.X., FENG S.L., YUN S., JIANG L.N., LU X.Y., HOU X.L. Effects of arsenic on seed germination and physiological activities of wheat seedlings. J. of Env. Sci., 19 (6), 725, 2007.

28. ARNON D.T. Copper enzyme in isolated chloroplasts polyphenoloxidase in Beta vulgaris. Plant Physiol., 24, 1, 1949.

29. MUKHERJEE S.P., CHOUDHURI M.A. Implication of water stressinduced changes in the levels of endogenous ascorbic acid and hydrogen peroxide in Vigna seedlings. Plant Physiol., 58, 166, 1983.

30. CAKMAK I., HORST W.J. Effects of aluminium on lipid peroxidation, superoxide dismutase, catalase, and peroxidase activities in root tips of soybean (Glycine max). Plant Physiol 83, 463, 1991.

31. VELIKOVA V., YORDANOV I., EDREVA A. Oxidative stress and some antioxidant systems in acid rain-treated bean plants: protective role of exogenous polyamines. Plant sci., 151 (1), 59, 2000.

32. GIANOPOLITIS C.N. RIESSk Superoxidedismutases I. Occurrence in higher plants. Plant Physiol 59, 309, 1977.

33. CHANCE M., MAEHLY A.C. Assay of catalases and peroxidases. Meth. in Enzym., 2, 764, 1955.
34. RODRIGUEZ-RUIZ M., APARICIO-CHACON M.V., PALMA J.M., CORPAS F.J. Arsenate disrupts ion balance, sulfur and nitric oxide metabolisms in roots and leaves of pea (Pisum sativum L.) plants. Env. and Exp. Bot., 161, 143, 2019.

35. CAO X., MA L Q. Effects of compost and phosphate on plant arsenic accumulation from soils near pressuretreated wood. Env. Pol., 132 (3), 435, 2004.

36. ANJUM S.A., TANVEER M., HUSSAIN S., ASHRAF U., KHAN I., WANG L. Alteration in growth, leaf gas exchange, and photosynthetic pigments of maize plants under combined cadmium and arsenic stress. Water, Air, \& Soil Pol., 228 (1), 13, 2017.

37. KUMAR S., DUBEY R.S., TRIPATHI R.D., CHAKRABARTY D., TRIVEDI P.K. Omics and biotechnology of arsenic stress and detoxification in plants: current updates and prospective. Env. Int., 74, 221, 2015.

38. LIU C., KONDO T., FERNANDES R.M., PALCZEWSKI A.D., MUN E.D., NI N., KAMINSKI A. Evidence for a Lifshitz transition in electron-doped iron arsenic superconductors at the onset of superconductivity. Nature Phy., 6 (6), 419, 2010.

39. PARVEZ S., ABBAS G., SHAHID M., AMJAD M., HUSSAIN M., ASAD S.A., NAEEM M.A. Effect of salinity on physiological, biochemical and photostabilizing attributes of two genotypes of quinoa (Chenopodium quinoa Wild.) exposed to arsenic stress. Ecotoxicology and Env. Safety, 187, 109814, 2020.

40. MALIK J.A., GOEL S., KAUR N., SHARMA S., SINGH I., NAYYAR H. Selenium antagonises the toxic effects of arsenic on mungbean (Phaseolus aureus Roxb.) plants by restricting its uptake and enhancing the antioxidative and detoxification mechanisms. Env. and Exp. Bot., 77, 242, 2012.

41. NATH S., PANDA P., MISHRA S., DEY M., CHOUDHURY S., SAHOO L., PANDA S.K. Arsenic stress in rice: redox consequences and regulation by iron. Plant Physiol. and Biochem., 80, 203, 2014.

42. KHALID S., SHAHID M., NIAZI N.K., RAFIQ M., BAKHAT H.F., IMRAN M., DUMAT C. Arsenic behaviour in soil-plant system: Biogeochemical reactions and chemical speciation influences. In Enhancing cleanup of environmental pollutants (pp. 97-140). Springer, Cham, 2017.

43. GU Z., FANG J., DENG B. Preparation and evaluation of GAC-based iron-containing adsorbents for arsenic removal. Env. Sci. \& tech., 39 (10), 3833, 2005.

44. CI X.K., LIU H.L., HAO Y.B., ZHANG J.W., PENG L.I. U., DONG S.T. Arsenic distribution, species, and its effect on maize growth treated with arsenate. J. of Integ. Agri., 11 (3), 416, 2012

45. ANJUM S.A., ASHRAF U., KHAN I., TANVEER M., SALEEM M.F., WANG L. (2016a). Aluminum and chromium toxicity in maize: implications for agronomic attributes, net photosynthesis, physio-biochemical oscillations, and metal accumulation in different plant parts. Water, Air, and Soil Pol., 227, 326, 2012.

46. CARBONELL-BARRACHINA A.A., BURLO F., VALERO D., LOPEZ E., MARTINEZ-ROMERO D., MARTINEZ-SANCHEZ F. Arsenic toxicity and accumulation in turnip as affected by arsenic chemical speciation. J. of Agri. Food Chem., 47, 2288, 1999.

47. ZHOU Z., KANG Y., LI H., CAO S., XU J., DUAN X., SHAO K. Estimating inorganic arsenic exposure from rice intake in Chinese Urban Population. Env. Pol., 114397, 2020. 
48. ABBAS G., MURTAZA B., BIBI I., SHAHID M., NIAZI N.K., KHAN M.I., HUSSAIN M. Arsenic uptake, toxicity, detoxification, and speciation in plants: physiological, biochemical, and molecular aspects. International Journal of Env. Res. and Pub. Health, 15 (1), 59, 2018.

49. HALIM M.A., MAJUMDER R.K., RASUL G., HIROSIRO Y., SASAKI K., SHIMADA J., JINNO $\mathrm{K}$. Geochemical evaluation of arsenic and manganese in shallow groundwater and core sediment in Singair Upazila, Central Bangladesh. Arab. J. for Sci. and Eng., 39 (7), 5585, 2014.

50. DHIR B., SHARMILA P., SARADHI P.P. Hydrophytes lack potential to exhibit cadmium stress induced enhancement in lipid peroxidation and accumulation of proline. Aqu. Toxicol., 66 (2), 141, 2004.

51. ZU Y.Q., SUN J.J., HE Y.M., WU J., FENG G.Q., LI Y. Effects of arsenic on growth, photosynthesis and some antioxidant parameters of Panax notoginseng growing in shaded conditions. International Journal of Adv. Agr. Res., 4, 78, 2016.

52. SHARMA I. Arsenic induced oxidative stress in plants. Biologia, 67 (3), 447, 2012.

53. SHAHID M., DUMAT C., KHALID S., SCHRECK E., XIONG T., NIAZI N.K. Foliar heavy metal uptake, toxicity and detoxification in plants: A comparison of foliar and root metal uptake. J. of Hazard. Mat., 325, 36, 2017.

54. IRSHAD S., XIE Z., WANG J., NAWAZ A., LUO Y., WANG Y., MEHMOOD S. Indigenous strain Bacillus XZM assisted phytoremediation and detoxification of arsenic in Vallisneria denseserrulata. J. of Hazard. Mat., 381, 120903, 2020.

55. RONZAN M., PIACENTINI D., FATTORINI L., DELLA ROVERE F., EICHE E., RIEMANN M., FALASCA G. Cadmium and arsenic affect root development in Oryza sativa L. negatively interacting with auxin. Env. and Exp. Bot., 151, 64, 2018.

56. KHALID S., SHAHID M., NIAZI N.K., RAFIQ M., BAKHAT H.F., IMRAN M., DUMAT C. Arsenic behaviour in soil-plant system: Biogeochemical reactions and chemical speciation influences. In Enhancing cleanup of environmental pollutants (pp. 97-140). Springer, Cham, 2017.

57. ASADA T. Stabilization policy in a Keynes-Goodwin model with debt accumulation. Struct. Change and Eco. Dyn., 17 (4), 466, 2006.

58. WANG C., NA G., BERMEJO E.S., CHEN Y., BANKS J. A., SALT D.E., ZHAO F.J. Dissecting the components controlling root-to-shoot arsenic translocation in Arabidopsis thaliana. New Phyto., 217 (1), 206, 2018.

59. MEDINA S., COLLADO-GONZÁLEZ J., FERRERES F., LONDOÑO-LONDOÑO J., JIMÉNEZ-CARTAGENA C., GUY A., GIL-IZQUIERDO A. Quantification of phytoprostanes - bioactive oxylipins - and phenolic compounds of Passiflora edulis Sims shell using UHPLCQqQ-MS/MS and LC-IT-DAD-MS/MS. Food Chem., 229, 1, 2017.

60. NOMAN A., ALI Q., NAHEED F., RIZWAN M., ALI S., IRSHAD K. Foliar application of ascorbate enhances the physiological and biochemical attributes of maize (Zea mays L.) cultivars under drought stress. Arch. of Agron. and Soil Sci., 61 (12), 1659, 2015.

61. LI S., LEI N., CHEN J. Differential Effects of Natural Palygorskite and its Modified Form on Alleviation of Heavy Metals Toxicity to Tomato Grown in Soil Contaminated with $\mathrm{Cd}, \mathrm{Pb}$ and $\mathrm{Zn}$. Polish Journal of Env. Stud., 28 (6), 2019.

62. HORE T.A. Modulating epigenetic memory through vitamins and TET: implications for regenerative medicine and cancer treatment. Epigen., 9 (6), 8631, 2017.

63. KAYA C., ASHRAF M., ALYEMENI M.N., CORPAS F.J., AHMAD P. Salicylic acid-induced nitric oxide enhances arsenic toxicity tolerance in maize plants by upregulating the ascorbate-glutathione cycle and glyoxalase system. J. of Hazard. Mat., 123020, 2020.

64. NOMAN A., ALI Q., MAQSOOD J., IQBAL N., JAVED M.T., RASOOL N., NASEEM J. Deciphering physiobiochemical, yield, and nutritional quality attributes of water-stressed radish (Raphanus sativus L.) plants grown from Zn-Lys primed seeds. Chemosphere, 195, 175, 2018a.

65. NAGAJYOTI P.C., LEE K.D., SREEKANTH T.V.M. Heavy metals, occurrence and toxicity for plants: A review. Env. Chem. Let., 8 (3), 199, 2010.

66. LI S., XU H., WANG L., JI L., LI X., QU Z., YAN N.. Dual-functional sites for selective adsorption of mercury and arsenic ions in [SnS4] 4-/MgFe-LDH from wastewater. J.1 of Hazard. Mat., 403, 123940, 2020.

67. NOMAN A., AQEEL M. miRNA-based heavy metal homeostasis and plant growth. Env. Sci. Pol. Res., 24 (11), 10068, 2017.

68. GAO Y., MIAO C.Y., XIA J., LUO C.Y., MAO L., ZHOU P., SHI W. Effect of citric acid on phytoextraction and antioxidative defense in Solanum nigrum L. as a hyperaccumulator under $\mathrm{Cd}$ and $\mathrm{Pb}$ combined pollution. Env. Earth Sci., 65, 1923, 2012.

69. NOMAN A., ALI Q., NASIM J., JAVED M.T., KANWAL, H., ISLAM W., AQEEL M., KHALID N., ZAFAR S., TAYYEB M., IQBAL N., BURIRO M., MAQSOOD J., SHAHID S. Sugar beet extract acts as a natural biostimulant for physio-biochemical attributes in water stressed wheat (Triticum aestivum L.). Acta Physiol. Plant., 40 (6), 110, 2018b.

70. BASU S., ROYCHOUDHURY A., SAHA P.P., SENGUPTA D.N.D ifferential antioxidative responses of indica rice cultivars to drought stress. Plant Growth Regul. 60 (1), 51, 2010. 